\title{
CHALLENGES OF INTERNATIONAL HUMANITARIAN LAW IN REGULATING CONFLICTS FROM THE ERA OF HYBRID WARFARE
}

\section{Zoran JOVANOVSKI}

\author{
Associate professor \\ Military Academy "General Mihailo Apostolski"-Skopje \\ E-mail:zoran.jovanovski@ugd.edu.mk
}

\begin{abstract}
Expectations of world peace and harmony were contested after the September 11 attacks. This notable act of terrorism foreshadowed the changing nature of international conflicts, by no means completely unknown complex techniques and tactics of warfare. Throughout history, mankind has encountered various types of warfare, but none of them was alike today's. The challenges of modern warfare are a result of the appearance of hybrid acts of action, which gave new segments and epithets in conducting armed conflict. The aim justifies the means, is the background and the motto that initiate the non-state actors to influence the achievement of significant geo-strategic goals, and thus to promote their impact on the world globally. The moment we thought that the International Humanitarian Law (IHL) was completed, and through the legislation, all possible variants were legally covered, the enemy found a new guerrilla way in which they would achieve their goal. This confirms the fact that the law is always late for one war, and on the other hand it challenges the world experts to begin analyzing the deficiency of the law and its compatibility to deal with the newest type of warfare. The flexibility and implementation capacity of the IHL regulations are the basic features and criteria that need to be met in order to minimize the casualties and collateral damage that are a direct result of international conflicts in the XXI century. To always keep up with the pace of the modern and at the same time to anticipate the unknown, is the challenge that the international law carries it with great responsibility on its back.
\end{abstract}

Keywords: IHL, conflict, challenge, applicability, hybrid warfare 


\section{Introduction}

There was once a clear distinction between war and peace, beginning and end, fighters and civilians, whether it was an internal or international conflict, as well as between its winners and losers (Василевски, 2002, p. 23). The trend to blur the line between war and peace is what we can see in the XXI century (Gerasimov, 2016, p. 23). The end of the Cold War forced the West not only to look for a new enemy, but also to search for a new type of warfare (Цветковски, 2017).

Wars changed. The conflicts that emerged in Gaza, Iraq, and Ukraine demonstrated that a new and different form of unconventional warfare is evolving. Irregular fighters who take part in these conflicts look for creative and often indirect ways to accomplish their goals, often without fighting in a conventional way. Despite their unconventional appearance, each group has some level of national support. Iran, some of the Gulf States and Russia are providing them with weapons, advice to Hamas, ISIL, and Ukrainian separatists (Barno, 2014).

IHL is that which seeks to humanize war within the limits of maximum possibilities (as far as the military needs allow it), even though war itself is an inhumane way of resolving international disputes. Hence, the purpose of the IHL, preventing excessive casualties, human suffering, and material destruction, which are not necessary to achieve the military goal during an armed conflict. IHL is part of the International Public Law, and many of its provisions are contained in international documents (conventions, declarations, protocols), and the states that have ratified them are obliged to fully comply with them. The main function of law on armed conflict is to limit and mitigate the accidents of war as much as possible. The aforementioned IHL is applied only during an armed conflict, but this does not imply its use in riots, i.e., demonstrations, isolated or secondary acts of violence that occur within a country (Василевски, 2002, p. 12).

The condition for an armed conflict to be declared as an international is to have at least two or more warring states, while domestic disputes are reduced to a smaller or larger group of people who disrupt peace and security within the country, and these prevail compared to the others. This distinction is not as simple as it seems, because the practice has shown that both types of conflict in which IHL is applied, internal armed conflict and international armed conflict, can exist within one territory or again one type of conflict can convert into another.

During the period between 1946 and 2016, there were two hundred fifty-nine armed conflicts. The number of decolonization disputes, as well as, international wars, has decreased. However, civil wars are often spiced up and exacerbated by external international intervention. While the number of militants has dwindled from a decade to a decade since 1992, the hope of an end to the post-Cold War conflict was interrupted in 2003. Since then, we have witnessed about 30-50 existing conflicts annually (Dupuy, et al., 2017). The Armed Conflict Survey has listed 37 high, medium, and low-intensity conflicts, 
with an estimated 167,000 people killed, half in the Middle East and a third in Syria alone. A year earlier, there were 42 active conflicts with 180,000 casualties. The conflict in Syria, which is definitely the de facto cause of the great wave of migration, is the deadliest since the end of the Cold War. Since 2012, the Syrian conflict has accounted for more than half (53\%) of the total number of victims of armed conflicts worldwide. It is followed by Iraq (12\%) and Afghanistan (12\%). The three major conflicts were accompanied by large proportions of terrorist activities and population displacement. Four years after the US invasion of Iraq in 2003, 2 million Iraqis were forced to seek a better life outside their own country and 1.7 million were internally displaced. (Dupuy, et al., 2017).

This leads us to the fact that IHL and its application is a crucial factor for the states, high level of implementation and rule of law means successful management of the situation. Insufficient respect of its provisions means huge damages and losses for both the state and the population. Different rights apply to different types of conflicts, so it is very important to be properly classified and recognized in order to implement the ones that meet the criteria. Suffering, bloodshed, loss of innocent human lives, fear and uncertainty what the next day brings are the things that characterize all armed conflicts. These were the main reasons why the International Humanitarian Law came into force and made significant effect globally.

Does the implementation of IHL's regulation in practice reaches its necessary levels? Do the parties to armed conflict have complete knowledge of the principles of warfare and have a moral responsibility to apply them? And finally, how reliable and effective is the system for detecting, protecting and sanctioning the parties to a conflict, especially for resolving conflicts from the hybrid era of warfare? The main aim of this manuscript is to express the results that emerged as the final answer of the research questions accordingly to the paper thesis.

\section{The complexity of the hybrid era of warfare}

Today's modern form of warfare is known as the fourth generation of warfare. The term itself began to be used in the late 1980s by military experts and strategists, a way of characterizing the dynamics and future directions of warfare. This generation does not emphasize the constant principles of warfare as the classic way of warfare. The fourth generation of warfare is moving towards taking advantage of the political, informational, economic, legal, and technical changes since World War II (Современа Македонска Одбрана, 2019, стр. 8).

Thus, the use of benefits of social change imposes an unconventional approach to warfare. The enemy of this generation is using a guerrilla way of acting, and we can say that they are inferior in technique and manpower, also in an operational and tactical view. This way of warfare is a battle of ideas, and the focus of this warfare is on changing the consciousness of decision-makers using the tools of systematic power and global influence. Diplomacy, 
information, economics, and the display of military force are the main tools for manipulating and initiating impact. There is, on the other hand, military part, a political set, followers or supporters and target groups that are used for manipulation. From a political point of view, transnational, international and national organizations and networks are covered by this type of warfare.

Examples of fourth-generation warfare include Iraq and Afghanistan, a modern form of insurgency. Convincing hostile political leaders that their strategic goals are unattainable or too expensive is precisely the goal of these practitioners (Современа Македонска Одбрана, 2019, стр. 9).Terrorism, ethnic conflict, civil wars, hybrid wars, and special operations (techniques used by developed nations to harass or destabilize enemies through non-traditional methods), represent a significant part of the non-state, inter-institutional, and interstate violence. Although XXI century has seen a significantly lower mortality rate in military conflicts compared to similar periods in the previous century, these figures display the tens of thousands of lives lost each year (Ray).

The very fact that both state and non-state actors are involved in this form of warfare makes hybrid warfare quite confusing and unpredictable. This complicates the manner of law enforcement, where the dilemma of which article is applicable needs to be resolved. The template of the new way of warfare was supposed to specify new procedures that over time would become even more necessary (Цветковски, 2017, p. 1). Although there is no universal definition for the concept of "hybrid war" or "hybrid threat", the Committee on Legal Affairs and Human Rights consider that the main characteristic of "hybrid war" is its "legal asymmetry", as hybrid opponents deny their activities and work on the very edge of the law. When there is no military action, domestic criminal law enters into force and implementation. But, in the case when military action is already present, the application of international law begins, especially the right to self-defense and humanitarian law. Human rights must be respected in all situations and circumstances, therefore any restriction on these rights must comply with the requirements of the European Convention on Human Rights.

Hybrid warfare encourages instability in a country's internal affairs by prioritizing non-kinetic military methods such as cyber acts, influence over operations in coordination with economic pressure, support for local opposition groups, disinformation, and criminal activity. The strategic benefit of hybrid warfare is to blur the role of the aggressor-state. Even the slightest form of denial can delay or fragment the opposition to actions that provoke a loud, sometimes coercive international response (Cantwell, 2017). The very notion of asymmetric conflict cannot be limited to armed conflicts between non-state actors and states, because states can be involved in this type of conflict. Asymmetry becomes a problem when parties to an armed conflict are unequal and legally structured differently. In other words, when a state struggles with a non-state entity that does not meet the criteria of Article 1 from Protocol II but consists of armed groups where there is no hierarchical command structure and which ignore all laws, both domestic and IHL (Cantwell, 2017). 
Hybrid warfare originally uses elements from four pre-existing methods and categories of warfare, namely irregular warfare (terrorism), asymmetric warfare (unconventional warfare as partisan rebels), while engaged by state actors to justify their conventional approach or by non-state actors using the hybrid model of warfare to gain an advantage over the enemy (Munoz Mosquera \& Bachmann, 2016).

\section{Challenges in Implementation of International Humanitarian Law when dealing with modern armed conflicts}

When political violence reaches the level of an armed conflict, whether international or non-international, the IHL implementation begins, which includes the four Geneva Conventions of 1949, their two Additional Protocols of 1977, and a number of other legally binding instruments and the customary law. Although the IHL does not directly provide a definition of terrorism, acts against civilians and civilian objects in armed conflict are explicitly prohibited, which would normally be considered as "terrorist act" if carried out in peace (Василевски, 2002).

One of the glaring gaps in the IHL concerns its very basis, namely the question of defining war or rather "armed conflict" in a more objective sense given the term from Article 2, common to the Four Geneva Conventions of 1949. A single definition may not cover all variants of modern armed conflict, leading to the fact that a new definition is needed to ensure the effective extension of basic humanitarian guarantees for the modern types of armed conflict. States can more easily argue that IHL is inapplicable, especially in conflicts involving non-state actors, if the activation of "jus in bello" applicability is the existence of an international or non-international armed conflict. Some authors argue that the definition of "armed conflict of a noninternational nature" deriving from Common Protocol 3 to the Geneva Conventions does not encompass the factual situations that reality poses.

First of all, it is not clear what level of violence must be reached and how long the hostilities must last. For example, we have situations where in the interior of the country, there are numerous conflicts with a high degree of violence, which are mainly for political reasons, which is not considered as an armed conflict. On the other hand, we have situations in which there is a much lower level of violence, and it replicates in a shorter period, but they are still considered as an armed conflict. Assessing the ability of armed groups to apply IHL and whether it should be seen at all as a criterion for identifying these groups as parties to the conflict is quite problematic. Conflicts between insurgent groups in Iraq and Afghanistan (al-Qaeda and the Taliban), US-led coalitions between Israel and non-state groups in the occupied territories and in Lebanon (Hamas and Hezbollah), the so-called "global war on terror" implemented a new sight of the applicability of international humanitarian law (Cantwell, 2017).

Understanding the relationship between international law governing the use of force and hybrid warfare is crucial for dealing with hybrid threats. In 
order to improve international protection for the territorial integrity and political independence of states, hybrid measures have been used and have been very successful. The ban of aggressive warfare refers to them as well. The need to impose such a ban stems from the very hybrid warfare that has introduced a new kind of aggression known as the "supreme international crime." The Rome Statute of the International Criminal Court states a general principle that aggression violates international law. This introduction of the law is declared as a measured progress, but still uncertain. Uncertainty arises precisely from the disagreement between states over the definition of aggression. Since the UN Charter entered into force, states have acted both multilaterally and unilaterally in dealing with aggression (Rome Statute of the International Criminal Court, 1998).

The U.S.-led International Coalition, formed to expel Saddam Hussein's forces from Kuwait is a sign of high collective will to deal with aggression. But in modern cases it is rare to use tactics and strategies where military forces will use hard power to occupy a certain territory. Nowadays, the act of aggression is less visible. From Russia's experience and actions with Georgia, Crimea, and eastern Ukraine, it can be concluded that hybrid measures need to be put in place under the permanent law, which they in fact want to circumvent (Cantwell, 2017).

Lawyers and experts suggest that hybrid conflicts should be a subject of discussion, according to official information of the Pentagon (Wittes, 2015). However, there are only international armed conflicts and internal armed conflicts, where the "hybrid" category is nowhere to be found. What has been concluded is that hybrid conflict is not something new and does not pose a serious challenge to the law, certainly not to the basic IHL related framework.

However, a few areas present more substantial challenges related to the cyber domain. One of the experts presented a scenario in which the operators detect incoming malicious network traffic, they identified that there are civilians behind it, but the problem is that they have no clear evidence whether those civilians work with or for the government. And also, they are not aware what risk level it is, whether it rises to the level of any form of attack or just espionage, which according to IHL is not prohibited at all. Precisely such phenomena, which occur on a huge scale, are something new on the global stage (What is Hybrid Conflict?, 2015). Another participant described this condition as complicated, which causes paralysis in the process of response - officials do not perceive what incoming traffic actually contains, so they do not know which law to apply, which results in lawlessness (not applying any law) (What is Hybrid Conflict?, 2015). The author of this article is of the opinion that this is not an IHL's problem, but for the founders of social networks, who should take care of it (Wittes, 2015).

During the occupation of Iraq, members of organized resistance movements, various armed groups fighting the coalition claimed to oppose the occupying forces. That raises the question whether members of these armed groups can qualify as combatants, who would have the privilege of being prisoners of war in the case of capture, or ones who participated directly in 
hostilities without the right to do so, which would not be the case to be protected by the III Geneva Convention. With the fall of Saddam Hussein's regime, various units of the government armed forces disintegrated, so the resistance in Iraq was led mainly by Iraqi civilians. However, after the collapse of the former regime, some members of his armed forces joined the resistance, although no member of the former armed forces claimed to be continuing the fight on behalf of the Saddam's rule.

By the very fact that their armies are disbanded, they lose the status of fighters, and their further action is like civilians. Members of "organized resistance movements" are entitled to the status of prisoners of war if they "belong to a party to the conflict" and meet the additional cumulative criteria set out in Article A part Two of the III Geneva Convention (Geneva Convention Relative to the Treatment of Prisoners of War (Third Geneva Convention), 1949). Despite the numerous coalition precautionary measures taken, the armed groups operating in Iraq were sufficiently organized, coordinated, and equipped successfully to carry out regular armed attacks, thus posing a permanent threat to coalition forces and the civilian population. Therefore, it can clearly be assumed that most of these groups represent each for themselves, organized paramilitary forces under a command in charge (Dörmann K \& Colassis L, 2004, p. 23).

\section{Cyberspace}

Cyberspace is still considered a space that is not well known and is still under development. The definition of the term cyber-war can be taken as the methods of warfare that rely on information technology and are used in situations of armed conflict. IHL will only apply to cyber operations that occur during a particular action or cause armed conflict themselves - which is the second part of the definition that is very important.

In cyberspace, there are unlimited ways to distract, disrupt or harm any system, network or database. There is a clear distinction between cyber warfare and cyberterrorism. Cyberwarfare is any virtual conflict initiated as a politically motivated attack on an enemy's computer and information systems. Waged via the Internet, these attacks disable financial and organizational systems by stealing or altering classified data to undermine networks, websites and services.

Cyberwarfare involves the following attack methods:

Sabotage: Military and financial computer systems are at risk for the disruption of normal operations and equipment, such as communications, fuel, power and transportation infrastructures.

* Espionage and/or security breaches: These illegal exploitation methods are used to disable networks, software, computers or the Internet to steal or acquire classified information from rival institutions or individuals for military, political or financial gain. (Cyber Warfare, 2017)

For their own safety, some of the biggest organizations tend to organize cyber attacks on their own systems, just in case they identify vulnerabilities for 
proper removal and defense. A common perception of a hacker is that of a teenage geek who breaks into computer systems for fun. While this perception was perhaps once true, modern cyberwarfare involves well trained, well-funded professionals backed by nation states.

On the other hand, cyberterrorism is defined as a premeditated attack against a computer system, computer data, programs and other information with the sole aim of violence against clandestine agents and subnational groups. The main aim behind cyberterrorism is to cause harm and destruction. Cyberterrorism can be explained as internet terrorism. With the advent of the internet, individuals and groups are misusing the anonymity to threaten individuals, certain groups, religions, ethnicities or beliefs. Cyberterrorism can be broadly categorized under three major categories:

* Simple: This consists of basic attacks including the hacking of an individual system.

* Advanced: These are more sophisticated attacks and can involve hacking multiple systems and/or networks.

* Complex: These are coordinated attacks that can have a large-scale impact and make use of sophisticated tools.(Cyber Terrorism)

\subsection{The applicability of International Humanitarian Law in cyber space}

The question (jus ad bellum) of whether a cyberattack could mean "use of force" or even an "armed attack" under the UN Charter conflicts, still remains uncovered. Determining the onset of an armed conflict in which independent cyberattacks occur without any kinetic force is complicated (Rodenhäuser, 2021). If the applicability of IHL is activated, the question arises whether the actions in cyber space called cyber attacks are in fact "attacks" within the meaning of Article 49 of Protocol I, and whether it is necessary for them to result in physical consequences such a $\mathrm{s}$ injury or death of persons or destruction of objects.

Depending on whether the actions in cyber space have a significant effect on the target side, some experts believe that they should be considered as attacks. Especially, if the actions taken resulted in simple destruction of data or interference in information systems. The cyber operation will have to comply with the principles of differentiation, proportionality, and precaution if it is triggered, the issue becomes an indicator of the adaptability of the rules for enforcing the enemies and assessing the damage. When looking at the division first, the nature of information networks puts the principle in an inconvenient zone, that is, many of the military networks are based on civilian infrastructure (optical cables, satellites), thus virtually switching the connection to a "dual-use" facility with civilian and military functions, which complicates the process of effectively recognizing military facilities and actions. Additionally, while information destruction is considered a crucial target in any cyber operation, military facilities are limited and fall within the scope of IHL. Therefore, the question arises when certain data, that by definition are declared 
as intangible objects, can be marked as a legitimate target. As for the action executors, will the hacker who executes orders and acts under the authority of a party to an armed conflict be directly accused of participating in hostile acts?

In addition, the application of the principle of proportionality in cyber operations is a significant and difficult task. The externally connected nature of cyberspace means that any act can result in endless influences and effects that could immediately be qualified as disproportionate to the force used to achieve a particular goal and gain an advantage over the enemy. Thus, another issue of concern is the attacks that do not result in human casualties and only cause a high degree of inconvenience to civilians. The feeling of insecurity, discomfort and instability are not included in the definition of proportionality, and the majority of experts interpret it correctly because causing stress, fear and irritation does not lead to the loss of human casualties and it does not directly affect the reduction of combat capability on the side of the conflict. Ultimately, the problem of interconnectedness also affects the precautionary principle, in particular the obligation of the parties to the conflict to take passive precautionary measures in segregation and qualification between military and civilian targets and the civilian population.

In terms of new challenges, experts met in Tallinn to discuss how IHL rules could be applied to cyber operations. This resulted in the introduction of the Tallinn agreement for the application of IHL in cyber warfare, which brought certain provisions for specified problems and controversies in the implementation of legislation in practice. Finally, it is essential to continue the discussion and analysis in order to determine whether traditional IHL rules provide significant protection for civilians from the effects of cyber warfare, not forgetting that certain cyber operations can have a huge humanitarian impact on the real world. This is one of the many areas where existing IHL regulations are inadequate since the environment of cyber operations is completely different from the traditional one. Until the new rules come into force, the existing ones need to be applied to the best of their ability and the Tallinn agreement implies relevant suggestions in order to facilitate the legal settlement of conflicts (Nguyen, 2014).

The term "rules for assets and methods of warfare" according to the IHL refers to a large and complex set of norms that are relatively fragmented and not systematically identified as such. The term "means of warfare" is used for the regulation of weapons, while the term "methods" encompasses a wider range of rules depending on the definition under consideration. "Methods" denote the manner in which weapons are used; in relation to weapons, "assets" are those that denote the same, weapon systems or platforms used for attack purposes. However, the concept of the method of warfare also encompasses any specific, tactical, or strategic ways of conducting hostilities, which are not particularly weapons-related and aim to defeat and weaken the enemy, such as bombing and specific tactics used for attack, such as high-altitude bombing. In the situation of law, the term "methods" is quite new. The comprehensive principle of IHL and methods of warfare show that the right of the parties to the conflict to choose the tactic and method of action is limited. Such principles 
limit the nature of warfare in order to prevent serious human rights abuses, as well as unnecessary suffering. Protocol I does not mention the principles as part of the basic rules under the segments of warfare, but only in the part of protection for the civilian population from hostile effects (International humanitarian law and the challenges of contemporary armed conflicts, 2019).

Specifically prohibited methods of warfare that are not literally related to primary weapons show the perfidy. There is no complete agreement list of specifically prohibited methods, which may vary by country. Some include specific methods of warfare that aim to spread terror, violence, use of human shields and manipulate the environment. In contrast, others interpret these methods as different prohibitions, as opposed to problems with the method of warfare. The exact content and overview of the term "method of warfare" according to the principles and rules of IHL still remain unclear. Indeed, while traditional prohibitions regulate and minimize the unnecessary use of force and inhuman injuries, they also restrict the use of certain weapons, as well as specific methods with special characteristics (Василевски, 2002).

\section{Violation of International Humanitarian Law and the consequences of incomplete implementation of the law}

The number of decolonization disputes, as well as international wars, has decreased. But civil wars are often spiced up and exacerbated by external international intervention. The daily life of the civilians affected by these conflicts is filled with fear, suffering, uncertainty what the next day brings. Non-selective attacks, deliberate targeting of civilians, looting and destruction of civilian property, use of civilians as shields, torture, rape, etc. are just some of the many things people go through in non-international armed conflicts. Lack of applicable rules and more importantly, insufficient compliance with IHL are the reasons for the consequences in these conflicts (Barno, 2014).

Even today, the burden of armed conflict is borne by civilians. The main victims of IHL violations committed by state actors and non-state armed groups are civilians. Some of the examples that are carried out regularly are: deliberate attacks on civilians, destruction of infrastructure vital to the civilian population and civilian property, forced displacement of the civilian population. Among them are numerous other violations of the law such as torture, enforced disappearance, murder, cruel treatment and insults to personal dignity, rape, and other forms of sexual violence, use of human bodies as shields. Persons detained during an armed conflict are deprived of basic human rights, including appropriate conditions and treatment while in detention, the right to a fair trial, and so on. In addition to civilians, medical staff and first aid workers have often been prevented from carrying out their activities or hindered in their efforts to do so effectively, further worsening the situation of those in need, which is a violation of IHL. Journalists and other media representatives were not left out, declared as victims to numerous attacks (International humanitarian law and challenges of contemporary armed conflicts, 2007, p. 741). 
The most current countries that can be taken as examples in which IHL violations have been reported are Iraq, Syria and Afghanistan. Because the clash of the armed combatants and regime's armed forces turned into armed conflict level, the International Independent Committee of the Syrian Republic began investigating violations of International Humanitarian Law (IHL)(Vito \& Asser, 2021). War crimes, crimes against humanity, including genocide and violations of international humanitarian law, have characterized the Syrian conflict since its March 2011 eruption.

The analysis showed a series of IHL violations in 14 categories, including:

$>$ attacks on civilians;

$>$ attacks against protected facilities;

$>$ use of prohibited, incendiary and chemical weapons unprecedented in recent wars, both in scale and intensity;

$>$ torture and ill-treatment;

$>$ children and vulnerable categories of citizens as victims and collateral damage, etc. (Ghaddar, et al., 2018, p. 418).

Murder, torture, rape, and enforced disappearance are among the evidence provided by the UN Commission of Inquiry, which proves that all parties to the conflict have committed war crimes. They are further accused of using civilian suffering as blocking access to water, food, and health services through sieges as a method of war (Syria: The story of the conflict, 2016). The term "humanitarian catastrophe" has a particularly profound meaning in relation to the situation in Syria. The existence of a "humanitarian catastrophe" is a trigger for action under certain doctrines of international law (Harrington, 2014).

The United Nations declared that 90,000 people were killed in the conflict by June 2013 (Syria: The story of the conflict, 2016), after three years of civil war, with an estimated more than 150,000 killed and by August 2015, that number had risen to 250,000. More than 2.5 million Syrians (over $10 \%$ of the population) have migrated to neighboring countries. In addition, at least 9.3 million Syrians inside Syria are in need of humanitarian assistance, of which over 6.5 million are internally displaced.

\section{Categories of International Humanitarian Law violations during the Middle East's conflicts}

\section{* Civilian distinction and protection}

The parties to the conflict are prohibited to attack civilians and must always distinguish between civilians and combatants, and civilian and military targets. The parties to the conflict must not undertake "non-selective attacks", and by their own decision to attack impermissible non-military targets that will disproportionately affect the course of hostilities. The majority of the casualties were killed by bombs dropped by government planes during rallies in rebelheld areas, which the UN says could be large-scale massacres. Investigators documented the "inherently indiscriminate" use of bombs, improvised 
explosive devices dropped by helicopters on densely populated civilian areas, deliberate targeting of children with sniper fire and deployment of cluster munitions, thermoduric bombs, and chemical weapons (Syria: 10 Years of War Crimes, Abuses, Human Rights Violations, 2021).The regulation on the distinction between civilian and military targets is often the subject of discussion due to the large volume of documented situations in which it is practically not applied, or it is violated. The use of bombs to act against civilian areas violates this rule. The UN Secretary-General announced in May 2014 that "indiscriminate airstrikes and shelling by both government and armed opposition forces have resulted in deaths, injuries and large-scale displacement of civilians." The civil war in Syria and the displacement of its people were labelled as the direct initiator and driver of the migrant crisis to reach its culmination in the period around 2015, and it had a direct impact on our country the main migrant route to Europe passes through.

\section{* Torture and inhumane treatment}

The use of torture is absolutely forbidden and cannot be justified by a state of emergency or war (Common Article 3 to the Geneva Conventions 1949; Articles 7 and 14 (2) (non-derogation) of the ICCPR; and Article 2 (2) of the Convention Against Torture, 1984). The Independent International Commission of Inquiry on Syria, set up by the UN Human Rights Council, has found evidence of widespread use of torture, as well as incidents of starvation and sexual violence in government prisons. Recently, some insurgent groups, such as the Islamic State of Iraq and the ISIL, have reportedly increased their use of illicit harassment and torture of civilians. Using civilian hunger as a method of warfare is absolutely unacceptable as an influence on civilians. This means that during the audit, the commission noticed reports of famine in areas besieged by the Syrian authorities, such as the siege of Yarmouk; civilians must be able to leave, and food and humanitarian supplies must have access to be delivered to the besieged and occupied area. The commission of inquiry noted reports of famine in areas besieged by Syrian authorities, such as Yarmouk. Human rights groups have accused the Syrian government of using hunger as a weapon of war.

\section{* Prohibition of using chemical and biological weapons}

The use of chemical and biological weapons in armed conflict is also strictly prohibited under the IHL. However, a chemical weapons attack was recorded on August 21, 2013, when hundreds of people were allegedly killed. A recent UN report on the situation in Syria also contained information on the use of a toxic gas. Hundreds of people were killed in August 2013, after rocketpropelled grenades were fired in several districts of Damascus. Western forces have blamed the Syrian government for the attack, while the government has blamed rebel forces. The Organization for the Prohibition of Chemical Weapons continued to document the use of toxic chemicals in the conflict after the operation. Investigators found that chlorine was used "systematically and 
consistently" in deadly attacks on rebel-held areas between April and July 2014 (Syria: The story of the conflict, 2016).

\section{* Protection of the personnel for humanitarian and medical help}

The protection of the humanitarian and medical aid personnel and their facilities is part of IHL which provides protection to both victims and injured casualties from the conflicts. Medical facilities must be protected, and they are not allowed to be attacked. In September 2013, a group of doctors published an open letter in "The Lancet" in which they cited "systematic attacks on medical professionals, institutions and patients - making it almost impossible to help victims and civilians to receive basic medical care and services" (Glinka, zur Hausen, \& Luiz D'Avila, 2013).Certain health facilities have been repeatedly attacked, confirming the fact that more than 460 health workers have been killed in Syria (Syrian Forces Responsible for 90 Percent of the 150 Attacks on Hospitals, 2014). UN personnel and medics have been detained or abducted by Syrian authorities and rebel groups (Report of the Secretary-General on the Implementation of Security Council Resolution 2139, 2014, p. 42).The United Nations reported that an estimated $\$ 3.2$ billion in humanitarian aid are needed because $70 \%$ of the population does not have access to adequate drinking water, one in three people is unable to meet their basic food needs, and more than 2 million children are unable to attend school. To exacerbate the problem, the warring parties refused to allow humanitarian agencies access to civilians in need of assistance, especially basic medical equipment (2016). For example, a report by the UN Secretary-General states: "Medical supplies, including rescue drugs and vaccines, as well as equipment for the wounded and sick, are wellprivileged through the Geneva Conventions. Denying these things is an arbitrary and unjustified and clear violation of the IHL. However, drugs are regularly denied to those in need, including tens of thousands of women, children and the elderly. The Security Council must take action to address these flagrant violations of the fundamental principles of international law" (Report of the Secretary-General on the Implementation of Security Council Resolution 2139 , 2014, p. 52). The Syrian government continued to reject requests for unhindered humanitarian access to Syria following Security Council Resolution 2139, adopted on 22 February 2014. Its preamble states that the arbitrary denial of humanitarian access may constitute a violation of the IHL.

\section{* Human right's violation and torture of prisoners of war}

The status of prisoners of war is regulated in detail by the Third Geneva Convention on the Treatment of Prisoners of War of 1949 and Protocol I to the Geneva Conventions (Articles 43-45), all other persons who are not recognized as prisoners of war have the right to a minimum guarantee of humane treatment as human beings and the civilizational right to a legal trial (Article 75 of Protocol I). In the early stages of the Iraq war, members of the US and CIA armed forces, under the direct command of Secretary of Defense Donald Rumsfeld, committed a series of human rights abuses and war crimes against detainees at the Abu Ghraib prison in Iraq. The case involved physical and 
sexual abuse, torture, rape, and murder. The crimes received media attention when photos of the CBS News abuse were published in April 2004. The incident caused shock and disbelief and raised the whole nation to its feet, causing global discontent in the United States and internationally (Hersh, 2004).

In response to the events at Abu Ghraib prison, the US Department of Defense removed 17 officers and soldiers from duty. Eleven of them were punished for breach of military duty, abuse, inhuman treatment, and violence. Between May 2004 and April 2006, these soldiers were indicted in a court of law, sentenced to military prison, and dishonestly removed from service by the United States military forces. Two soldiers were charged with committing the most heinous injuries in prison, namely Charles Grener and Lindy England. They were subject to additional penalties and sentenced to harsher sentences. Apart from these cases, many other mark the horror of the prisoners in Abu Ghraib prison. These included forming a pyramid of human bodies on the ground, intimidating hungry dogs, tying prisoners inhumanely, urinating on them, punching them while they were tied to the ground, spilling phosphoric acid on them and more (Hersh, 2004). As an example of a crime in Afghanistan, the two terrorist suicide attacks on April 30, 2018 in Kabul in a time interval of 20 minutes which killed 31 civilians, including nine journalists and a photographer. The bomber struck shortly afternoon in front of a crowd of protesters, killing at least 40 journalists and medical personnel.

The past years have been characterized by the increase of public awareness of IHL and its basic rules, as well as acts of violence and acts that violate those rules, although the suffering inflicted during the conflict has not changed. The focus was not only on the usual expert debates, but even more on academic, governmental, and media oversight of IHL principles and standards. Given the fact that knowledge of any rule is a prerequisite for better implementation, interest and awareness of IHL must be increased. In the two additional protocols, in the sections related to hostilities, actions aimed at spreading terror among the civilian population are prohibited. Additional Protocol I (Article 51 (2)) and Additional Protocol II (Article 13 (2)) provide that: "The civilian population as such, as well as individuals, should not be attacked". Acts or threats of violence, that have the primary aim of spreading terror against the civilian population, are prohibited.

The tendency of states to label all hostilities committed by organized armed groups during armed conflict as "terrorist", especially in noninternational armed conflict, was a challenge to the IHL. While it is generally accepted that under the IHL, parties to an international armed conflict can legally attack each other's military targets, states involved in non-international armed conflicts label any act by domestic insurgents as an act of "terrorism", refusing to acknowledge that the same principle applies to non-international armed conflicts. The key difference between IHL and the legislation governing terrorism is the fact that certain acts of violence against military objectives are not prohibited - based on the IHL presumption, but any act of "terrorism" is prohibited and criminal (International humanitarian law and challenges of 
contemporary armed conflicts, 2007).The discussions led by regional experts, at seminars organized by the ICRC in 2003 showed the improvement of IHL compliance as the most challenging in non-international armed conflicts, more precisely in relation to non-state parties in such conflicts. The search for new methods to achieve better implementation and enforcement of humanitarian law must be seen as a priority. Typically, a state or armed group that is a side of a non-international armed conflict can deny the applicability of the IHL. Government forces may claim that there is a situation of "tension" or some other activity, such as terrorism, which is not a non-international armed conflict, so that the same situation cannot be qualified as an armed conflict. On the other hand, not only government forces, but also non-state armed groups can deny the applicability of the IHL on the grounds that it is a subject of law created by states and that they cannot be bound by obligations ratified by the government that they are fighting against. In such cases, the law will rarely be a relevant reference framework, especially for groups whose actions are shaped by a strong ideology. The lack of political will to implement the IHL can be taken into account for the insufficient respect of the IHL.

\section{Conclusion}

It is popular to say that the law is always one step behind regarding one generation of war. The IHL regulations have not predicted against the modern methods of warfare, asymmetric threats, terrorism, and cyber-warfare. On the other side, like every written law it may contain vulnerable parts and therefore to be overwhelmed by a valuable strategy of warfare. Situations these days can be reviewed as confusing, including the dilemma of which regulation should be applied. The rules written for a specific war where everything is covered and known, remain only on a piece of paper as a document. In practice, warfare is an action or event that is characterized by many intertwined and complex factors that affect its onset and course. The impact on war, as well as its state or non-state players, the use of conventional or unconventional means of personal and mass destruction, the doctrines and tactics of warfare and their legal regulation by law, is a challenge facing the world legal community. Thus, the impossibility of legal coverage and regulation of all combat acts and actions gives the parties to the armed conflict the opportunity to abuse these legal shortcomings. From the warring countries of the XXI century that were subject of this research paper, we can conclude that despite the regulations and restrictions, the level of human rights violations is still high, perceived as a global problem and de facto the main initiator of civilian suffering and collateral war damage.

World research and debates suggest that the military law is still fully prescribed and can be applied to modern conflicts in some way. Others do not agree and consider that it is necessary to introduce new laws, to amend the IHL, which would include modern ways of warfare as the main epi thet of conflicts in the modern world.We can see that the actions of terrorists 
through suicide bombers are slowly becoming obsolete, at the cost of which cyber-attacks are increasing. When it comes to electronic attacks on systems and data, for now it is very difficult and almost impossible to find out who the attacker is, and even more the person who ordered the act, which leads to the fact that certain sanctions cannot be taken. Analyses confirm that cyberspace is still evolving, and countries with more advanced cyber technology can easily penetrate the systems of weaker countries that have not developed computer protection programs yet. Such cyber-attacks and hacking into the enemy system crucially and urgently need a legal doctrine to regulate such cyber security breaches. Major economic forces and state players began to create armies in the space and therefore territorial battle for the space. From that point, we can conclude that International Humanitarian Law has an express need for modernization and progress that would provide legal protection to the parties to modern conflicts that await to mark

the future of warfare.

The security of the individual, the side of an armed conflict and the confirmation of human rights in the future, should be of utmost priority, which would lay the fundaments for a secure and stable world of warfare. The act of mankind using different methods of warfare for achieving various goals has started from the very beginning of human existence and it will last in the future, forever.

\section{References}

Barno D. The shadow wars of 21st century. War on the rocks, July 2014.

Cantwell D. Hybrid Warfare: Aggression and Coercion in the Gray Zone. American Society of International Law, November 2017. (Accessed $15 / 10 / 2021)$, https://www.asil.org/insights/volume/21/issue/14/hybrid-warfare aggression-and- coercion-gray-zone.

Common Article 3 to the Geneva Conventions 1949; Articles 7 and 14 (2), (non-derogation) of the ICCPR; and Article 2 (2) of the Convention against torture 1984.

Cyber Warfare, International Committee of Red Cross. Retrieved from https://casebook.icrc.org/highlight/cyber-warfare.

Dörmann K., Colassis L., International Humanitarian Law in the Iraq Conflict. German Yearbook of International Law. Berlin, 2004, p. 23.

Gerasimov V. "The Value of Science Is in the Foresight: New Challenges Demand Rethinking the Forms and Methods of Carrying out Combat Operations." Military review 96 (2016): p. 23.

Ghaddar F., Jawwad M., Abdel Khalik R., Abou Zeid M., Sabouni A., AlNahhas H., Violations of international humanitarian law in Syria: A 7-year analysis. European Journal of Public Health, November 2018.Retrieved

from 
Challenges of International Humanitarian Law in regulating conflicts...

https://academic.oup.com/eurpub/article/28/suppl_4/cky218.026/5191 974.

GhaddarF., Jawwad M., Abdel Khalik R., Abou Zeid M., Sabouni A., AlNahhas H., Violations of international humanitarian law in Syria: A 7-year analysis. European Journal of Public Health, November 2018. p. 418. Retrieved from

https://academic.oup.com/eurpub/article/28/suppl_4/cky218.0 26/5191974.

Harrington N., International Legal Consequences of the Conflict in Syria, 2014. Retrieved from https://www.ennonline.net/page/renderforpdf/4809.

Hersh, S. M. (April 30, 2004). Torture at Abu Ghraib, The New Yorker. Retrieved 11 October, 2021 from https://www.newyorker.com/magazine/2004/05/10/torture-at- abughraib.

Hersh, Seymour Myron (June 25, 2007). "The General's Report: how Antonio Taguba, who investigated the Abu Ghraib scandal, became one of its casualties". The New Yorker.

International humanitarian law and challenges of contemporary armed conflicts, International conference of the Red Cross and Red Crescent. ICRC. Geneva, Switzerland, September 2007.

Munoz Mosquera, A. B., \& Bachmann, S. D. (2016). Lawfare in Hybrid Wars: The 21st Century Warfare, Journal of International Humanitarian Legal Studies,7(1), 63-87. Retrieved from https://doi.org/10.1163/1878152700701008.

Open Letter: Let us Treat Patients in Syria, The Lancet, 16 September 2013; Retrieved from http://www.thelancet.com/journals/lancet/article/PIIS01406736(13)61 938-8/fulltext.

Physicians for Human Rights calculates that Syrian government forces are responsible for $90 \%$ of 150 reported attacks on hospitals. Retrieved from https://phr.org/news/new-map-shows-government-forces deliberately-attacking- syrias-medical-system/.

Ray M. 8 Deadliest Wars of the 21st Century. Britannica. Retrieved from https://www.britannica.com/list/8-deadliest-wars-of-the-21st-century.

Report of the Secretary-General on the Implementation of Security Council Resolution 2139 (2014), 23 April 2014.

Retrieved from https://warontherocks.com/2014/07/the-shadow-warsof-the-21st-century/.

Rome Statue of the International Criminal Court. International Criminal Court, Hague, July 1998.

Syria: 10 Years of War Crimes, Abuses, Human Rights Violations. Organized crime and corruption reported projects, February 2021. Retrieved from https://www.occrp.org/en/daily/13915-syria-10-years-of-war-crimesabuses- human-rights-violations.

The International Independent Commission of Inquiry on Syria cites removal of essential medical and surgical supplies from aid convoys, 
resulting in scarcity of the most basic medical necessities such as syringes, bandages and gloves. Oral Update, 16 June 2014.

Vasilevski, V. (2002) International Humanitarian Law, Military Academy "General Mihailo Apostolski", Skopje.

Wittes B. What Is Hybrid Conflict? Cybersecurity LOAC-Military, September 2015. Retrieved from https://www.lawfareblog.com/what-hybridconflict.

Современа Македонска Одбрана бр.20 (Contemporary Macedonian Defence No.20), Ministry of defence of RNM. Skopje, 2019.

Цветковски C. Трансформација на војувањето низ призмата на асиметричноста (Transformation of warfare through the prism of asymmetrics). Годишен зборник, Филозофски факултет - Скопје (Yearbook of the Faculty of Philosophy - Skopje), 2017. 